\title{
The Sesame (Sesamum indicum L.) Value Chain and Microbiological Quality of Crude Sesame Oil, a Case Study in Western Tigray, Ethiopia
}

\author{
Abrehet F. Gebremeskel ${ }^{1 *}\left(\mathbb{0}\right.$, Peninah N. Ngoda1, Elizabeth W. Kamau-Mbuthia ${ }^{2}$, \\ Symon M. Mahungu ${ }^{1}$ \\ ${ }^{1}$ Department of Dairy and Food Science and Technology, Egerton University, Njoro, Kenya \\ ${ }^{2}$ Department of Human Nutrition, Egerton University, Njoro, Kenya \\ Email: *abifish3@gmail.com
}

How to cite this paper: Gebremeskel, A.F., Ngoda, P.N., Kamau-Mbuthia, E.W. and Mahungu, S.M. (2021) The Sesame (Sesamum indicum L.) Value Chain and Microbiological Quality of Crude Sesame Oil, a Case Study in Western Tigray, Ethiopia. Food and Nutrition Sciences, 12, 1306-1325. https://doi.org/10.4236/fns.2021.1212096

Received: October 14, 2021

Accepted: December 24, 2021

Published: December 27, 2021

Copyright $\odot 2021$ by author(s) and Scientific Research Publishing Inc. This work is licensed under the Creative Commons Attribution International License (CC BY 4.0).

http://creativecommons.org/licenses/by/4.0/

(c) (i) Open Access

\begin{abstract}
Crude sesame oil (CSO) is the widely used unrefined edible oil. Storage instability, off-flavour, and discoloration are, however, challenges in the industry. The purpose of this study was to map the sesame value chain, assess the suitability of CSO extraction plant, and analyze the microbial quality of CSO and premises environment. A structured Questionnaire and checklist were used to assess the sesame value chain and evaluate the suitability of the CSO extraction plant. Microbiological quality assessment was conducted using standard analytical methods. Stakeholders in the sesame value chain were inclusive of farmers, market mediators, traders, regulatory, extension workers and researchers. Though, illiteracy, inadequate technology, and infrastructure were the drawbacks. The CSO extraction plant was suitable apart from inadequate ingredients and CSO handling and unhygienic practices. Total aerobic bacteria (4.34 - $5.06 \log _{10} \mathrm{CFU} / \mathrm{m}^{2}$ on swap surfaces, $2.44 \log _{10} \mathrm{CFU} / \mathrm{g}$ in CSO), total Coliforms (5.81 $\log _{10} \mathrm{CFU} / \mathrm{g}$ of animal manure and $1.36 \log _{10}$ CFU of indoor air after extraction), yeasts and moulds $\left(2.31 \log _{10} \mathrm{CFU} / \mathrm{g}\right.$ of sesame seed and CSO and $4.47 \log _{10} \mathrm{CFU} / \mathrm{m}^{2}$ of swap sample), Aspergillus species (1.17 - $1.33 \log _{10} \mathrm{CFU} / \mathrm{g}$ of sesame seed/CSO, $3.37-3.50 \log _{10} \mathrm{CFU} / \mathrm{m}^{2}$ of swap samples), and Staphylococcus aureus (2.09 $\log _{10} \mathrm{CFU} / \mathrm{g}$ of CSO, 2.56 $3.22 \log _{10} \mathrm{CFU} / \mathrm{m}^{2}$ of surface swaps, $3.26-3.77 \log _{10} \mathrm{CFU} /$ protective clothing, $0.74-1.82 \log _{10} \mathrm{CFU}$ of the indoor and outdoor air) were detected. Escherichia coli, Salmonella and Shigella were not detected. In conclusion, potential microbial pathogens were detected to impose food safety problems and economic loss. To improve the sesame value chain and CSO quality workers training on good handling and hygienic practices and thoughtful regulatory implementation are significant.
\end{abstract}




\section{Keywords}

Crude Sesame Oil, Value Chain, Suitability, Microbial Quality, Pathogens

\section{Introduction}

Sesame (Sesamum indicum) is a flowering annual plant, belonging to the family Pedaliaceae. It requires an average of 90 days from the time of plantation till maturity [1]. It is tolerant to drought and flexible to different soil types, harsh conditions, diversified agro-ecological conditions and the pod bursts when it reaches maturity. Sesame is sensitive to a number of environmental and biological factors such as rainfall, wind, hotness and harvesting time [2], soil quality and moistness [3], which impacts productivity and quality. The global sesame production is about 2.211,339 million tons. Sesame production in Ethiopia is about 262,654 tons by 2019 (307 million USD) [4] about 8.96\% share in the global sesame market [5]. Sesame productivity in western Tigray is within the range of $2044 \mathrm{~kg} / \mathrm{ha}-400 \mathrm{~kg} / \mathrm{ha}$ while highly variable with and without the application of insecticides $651 \mathrm{~kg} / \mathrm{ha}$, average [5] variability with sesame breed, plantation location, use of fertilizers and agricultural practices with an average yield obtained $400 \mathrm{~kg} / \mathrm{ha}$ [4]. Sesame productivity yield is as high as $2044 \mathrm{~kg} / \mathrm{ha}$ [6] and (1161.5 kg/ha $-756.5 \mathrm{~kg} / \mathrm{ha})$ regardless of the variation of cultivation year, varieties and agro-climatic condition [7].

Food-borne illness is a serious problem that is appealing to global attention due to widespread disease and public outcry. Food Safety practices are very important in the food value chain to protect public health as well as food and economic security [8] [9]. It is essential to understand all possible hazards (microbial, chemical, and physical) existing or retrieving within the food value chain for better food safety practices. Microorganisms that exist in the environment, food, soil, water, and other associated animals might be a potential hazard to human, animal, and the environment. Microbial prevalence assessment and their severity to cause complications is critical for safer food distribution, quality assurance and develop operational practices. However, Inadequacy of good practices and written plans remain a challenge due to numerous reasons such as insufficient skill [10], inadequate safety practices, failure to implement and control good processing and handling practices [11], unhygienic conditions [12] [13], lack of transparency [14], inappropriateness of technology, and financial constraints [15].

Microorganisms colonize in a dynamic environment and a reason for a wider spectrum of infection [16] in all food categories in the value chain and associated surfaces [17] [18] [19], dairy value chain [20] [21], meat value chain [22] [23], and ready-to-Eat and salad [24] [25] Public health is threatened due to the prevalence of live organisms and their metabolites in food or ingested, contact is made with contaminated surfaces and inhaling of polluted air. Food poison- 
ing/infection occurs after 30 minutes or a few hours of food consumption. The severity of sickness depends on the nature of the microbe and its metabolites apparent for three or more days to manifest [26]. Symptoms of foodborne illness include nausea, vomiting, diarrhoea, abdominal pain, Headache, and chills with/without fever [27], acute gastroenteritis [28], and sepsis infection [29]. Skin and soft tissues inflammation and blemishes atopic dermatitis which triggers expression of cytokine [30]. Microbial poisoning or infection is persistent in a wider group of population [31] causes a high mortality rate among children [32] [33] [34]. Microbial-induced illnesses evade the host immune system and bone impairment [35].

Crude sesame oil (CSO) is the quality oil widely used as cooking oil, salad dressing, blending component in the oil refinery, and ointment. CSO studied in this study is unrefined mechanically extracted sesame oil in a small-scale extraction plant. CSO develops off-flavour, discoloration, and unstable during storage. The causes for the quality and storage instability of CSO might be associated with the prevalence of contaminants due to inappropriate handling and poor hygienic practices. The purpose of this study was to assess the Sesame value chain, CSO extraction plant suitability, hygienic practices, and microbial quality to reduce oil loss, improve stability and promote good practices.

\section{Materials and Methods}

\subsection{Study Design and Setting}

Survey data was collected in western Tigray, Ethiopia (latitude 14.032334 and longitude 38.316573$)$, temperature $\left(17.5^{\circ} \mathrm{C}-41.7^{\circ} \mathrm{C}\right)$, and altitudes $(500-1300$ meters) above sea level and rainfall $(480-633 \mathrm{~mm})$ [2] in the period between August 2019 to February 2020. A questionnaire was distributed (320 participants), presented in Table 1 drawn according to [36] to outline the sesame value chain and stakeholders in the value chain as indicated in Figure 1. A checklist was used to assess the suitability of the plant for CSO extraction as summarized in Table 4.

\subsection{Sample Collection}

Sesame seed, CSO, and water were sampled to examine for the prevalence of microbial contaminants. The source of microbial contamination was traced from the environmental air, the surface of the machinery and premises, protective clothes, and supplies. Sesame seed (100 g) was sampled from the CSO extraction store using a grain sampler from the bottom, top, and middle of the package, harvested during 2019/2020 in western Tigray. The seed was cleaned, homogenized, grounded (mortar and pestle grinder), and sieved $1 \mathrm{~mm}$ mesh size. About $10 \pm 0.05 \mathrm{~g}$ of grounded sesame seed was mixed with $90 \mathrm{ml}$ peptone water, diluted, transferred aseptically to the appropriate agar containing petri dish. CSO $(100 \mathrm{ml})$ was sampled in a blue-brown glass bottle and $1 \mathrm{ml}$ of CSO was aseptically transferred to media for microbial prevalence testing. Pipe Water $(100 \mathrm{ml})$ 
Table 1. Characteristics of stakeholders involved in the sesame value chain in western Tigray, Ethiopia $(\mathrm{n}=320)$.

\begin{tabular}{|c|c|c|}
\hline Variables & Frequency & Percent \\
\hline \multicolumn{3}{|l|}{ Gender } \\
\hline Women & 119 & 37.2 \\
\hline Men & 201 & 62.8 \\
\hline \multicolumn{3}{|l|}{ Age (years) } \\
\hline $18-25$ & 7 & 2.3 \\
\hline $26-30$ & 75 & 23.3 \\
\hline$>30$ & 238 & 74.4 \\
\hline \multicolumn{3}{|l|}{ Experience (in years) } \\
\hline$<1$ & 15 & 4.7 \\
\hline $1-2$ & 60 & 18.6 \\
\hline $2-5$ & 119 & 37.2 \\
\hline$>5$ & 126 & 39.5 \\
\hline \multicolumn{3}{|l|}{ Educational status } \\
\hline No formal education & 82 & 25.6 \\
\hline $8^{\text {th }}-12^{\text {th }}$ grade & 90 & 27.9 \\
\hline Certificate and above & 150 & 46.7 \\
\hline \multicolumn{3}{|l|}{ Role of stakeholders } \\
\hline Market intermediary & 21 & 6.7 \\
\hline Traders & 71 & 22.2 \\
\hline Farmer & 86 & 26.7 \\
\hline Regulatory authorities & 29 & 8.9 \\
\hline Technical expert & 87 & 27.2 \\
\hline Researcher & 26 & 8.2 \\
\hline \multicolumn{3}{|l|}{ Communication } \\
\hline Telephone & 160 & 50 \\
\hline Letter & 40 & 12.5 \\
\hline Telephone, Letter and Internet & 120 & 37.5 \\
\hline \multicolumn{3}{|l|}{ Management Support } \\
\hline No & 60 & 18.9 \\
\hline Yes & 260 & 81.1 \\
\hline
\end{tabular}




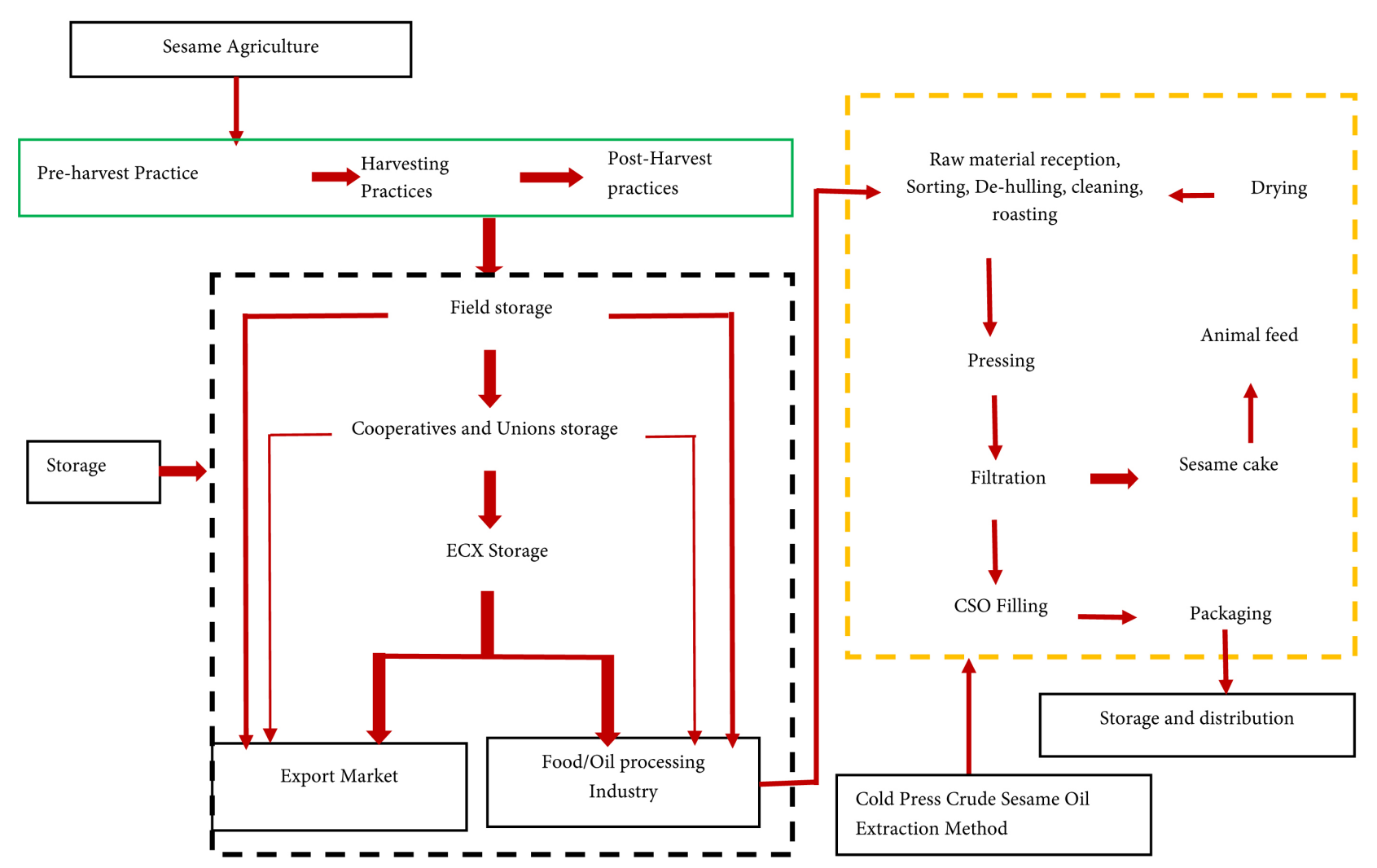

Figure 1. Schematic description of sesame value chain in western Tigray, Ethiopia.

were sampled in a blue-brown glass bottle after 1 - 2 minutes flow and groundwater $(100 \mathrm{ml})$ fetched from the hole in a polyethylene plastic placed in a blue-brown glass $(100 \mathrm{ml})$ in an ice-pack to analyse the microbial quality within 2 hours. The surface of the milling and pressing machine, filtration machine, filling machine, the floor of sesame store, and wall of the extraction room was swabbed. Swabbing was performed in a $10 \times 10 \mathrm{~cm}$ area, in difficult to clean or reach surfaces scrubbed in two perpendicular directions using a moistened cotton swab in buffered peptone water. Protective gown from inner underarms and the inner side of clove was sampled by peptone water moistened cotton swap scraped, placed, and kept for 5 minutes. The swab sample was placed in a sterilized plastic bag, break-off in a test tube according to the method described by [37]. The indoor and outdoor air sample was collected during/after production using a passive sampling method $1 \mathrm{~m}$ above the floor and $1 \mathrm{~m}$ away from the wall in an agar media containing petri dish (140 mm diameter) left open for 1 hour according to the procedure of ISO 14698 air sampling described by [38]. Incubation methods for microbial cultivation were performed as summarized in $\mathrm{Ta}$ ble 2.

\subsection{Microbial Enumeration}

Microbial colonies were enumerated using an illuminated magnifying colony counter, organized in an excel Microsoft transformed into $\log _{10}$ colony-forming 
Table 2. Summery of microbial assessment methods applied to assess CSO microbial quality and CSO plant.

\begin{tabular}{|c|c|c|c|}
\hline $\begin{array}{c}\text { Target } \\
\text { microorganism }\end{array}$ & Agar & $\begin{array}{l}\text { Incubation } \\
\text { condition }\end{array}$ & Method \\
\hline $\begin{array}{l}\text { Aerobic plate } \\
\text { count }\end{array}$ & $\begin{array}{c}\text { Pour plate methods in a } \\
\text { Plate count agar (AOAC 966.23) }\end{array}$ & $37^{\circ} \mathrm{C} / 48 \mathrm{~h}$ & [39] \\
\hline Total Coliforms & $\begin{array}{l}\text { Pour plate method in a } \\
\text { Plate count agar (ISO 9308-1:2014) }\end{array}$ & $37^{\circ} \mathrm{C} / 48 \mathrm{~h}$ & {$[40]$} \\
\hline Escherichia coli & $\begin{array}{l}\text { Pour plate method in a } \\
\text { MacConkey agar }\end{array}$ & $44.5^{\circ} \mathrm{C} / 24 \mathrm{~h}$ & {$[41]$} \\
\hline Yeast/mould & $\begin{array}{l}\text { Spread plate method in a Rose } \\
\text { Bengal Chloramphenicol Agar }\end{array}$ & $22^{\circ} \mathrm{C} / 7$ days & {$[42]$} \\
\hline $\begin{array}{l}\text { Aspergillus } \\
\text { fungi }\end{array}$ & $\begin{array}{l}\text { Sabouraud Dextrose Agar } \\
\text { chloramphenicol powder } \\
\text { as anti-bacterial growth inhibitor }\end{array}$ & $25^{\circ} \mathrm{C} / 5$ - 7 days & {$[43]$} \\
\hline $\begin{array}{l}\text { Salmonella } \\
\text { and Shigella }\end{array}$ & $\begin{array}{l}\text { Xylose lysine desoxycholate agar with } \\
\text { Rappaport-Vassiliadis Soy Peptone Broth }\end{array}$ & $37^{\circ} \mathrm{C} / 18 \mathrm{~h}$ & {$[44]$} \\
\hline $\begin{array}{l}\text { Staphylococcus } \\
\text { aureus }\end{array}$ & $\begin{array}{l}\text { Mannitol Salt Agar (Oxoid), } \\
\text { gram staining, coagulase test }\end{array}$ & $32^{\circ} \mathrm{C} / 48 \mathrm{~h}$ & {$[45]$} \\
\hline
\end{tabular}

units. The microbial colony was expressed as $\log _{10} \mathrm{CFU} / \mathrm{g}$ for sesame seed, $\log _{10}$ $\mathrm{CFU} / \mathrm{ml}$ for CSO and water, $\log _{10} \mathrm{CFU} / \mathrm{m}^{2}$ for swab samples, and $\log _{10} \mathrm{CFU} / \mathrm{hr}$ for air sample.

\subsection{Data Analysis}

A questionnaire was presented and later translated into local language (Tigrigna) for a comprehensive understanding of the terms and articulated after random questioner distribution. The questionnaire with missing responses was cleaned, inserted into IBM SPSS Statistics version 22 software to generate descriptive data (frequency and percentage) of respondents involved in the sesame value chain. The suitability of the plant for oil extraction and sanitary conditions was tabulated. The APC, total Coliforms, fungi, Aspergillus species, staphylococcus aureus count colonies data were tabulated and converted $\log _{10}$ colony-forming units in an excel sheet, and analysis was performed using analysis of variance (ANOVA) in a SAS V8 software to separate the means and standard deviations. Tukey was used to test for statistical significance difference at a P-value of 0.05 .

\section{Results and Discussion}

\subsection{Stakeholder Characterization}

Stakeholders in the sesame value chain were farmers, researchers, regulatory authorities, technical experts, and traders with active and passive participation, as presented in Table 1. Stakeholders were gender-inclusive (37.2\% women, $62.8 \%$ men) and sesame farmers $(26.7 \%)$ at different scales of farming. In excess of $74 \%$ of the stakeholders were more than 30 years of age increases commit- 
ment and effective resource utilization for improved sesame value chain [1]. The composition, education, and experience of stakeholders in a particular value chain improve farming, value addition, and resource utilization [46]. Stakeholders with no formal education (25.6\%) were small-scale farmers and low-wage employees. Studies reported that farmers and low-wage employees with inadequate technology and traditional farming practices intensify sesame post-harvest and economic loss [47] [48]. Farmers' farming practices were laborious and time-consuming in particular the small farmers are lack or unaffordability rent of sesame driller/ploughing machine [49]. Besides the economic value, safety might be compromised due to the prevalence of toxigenic microorganisms, see Table 5. Stakeholders in the sesame value chain operate their routine practices with inadequate support and lack of training $(18.9 \%)$ on pesticide use, lack of access to improved seed variety, disease, and pest attack and weed prevention, sesame harvesting and handling, value addition, and market linkage [5].

Stakeholders with technical expertise surveyed (27.2\%) were an agricultural extension, soil and water conservation, pest control, post-harvest management, community health, and post-harvest technology. Regulatory (8.9\%) were from health extension, agricultural specialist to control the use of pesticides, post-harvest technologist and food scientists regulate agro-processing including sesame based products processing. A multi-disciplined researcher (8.2\%) with the aim of improving sesame productivity, introducing sesame new breeds and diseases resistances [50], post-harvest handling, and loss reduction, and value addition [47] [51] were involved. Traders (22.2\%) include cooperatives, unions and individuals who supply sesame to the global market guided through the Ethiopian commodity exchange office (EXC) (market intermediary, 6.7\%) or to the local market. Obtaining reliable and timely market information, financial constraints, deviation price setting, and identifying marketing channels are the challenges of sesame traders [52] [53]. Sesame traders collect sesame and store in a thin metal sheet-built storage warehouse or well-cemented block warehouses. The metal warehouses were not clean of grasses and bush around. While, sesame storage in a warehouse build of blocks, cemented floor, inlet/exit door, and windows with sufficient space and a recommended side dimensions were clean of grasses and bush. However, extended storage, loading, and unloading, transportation, and packaging incur high economic loss besides the field pre-harvest loss.

\subsection{Sesame Value Chain}

Sesame (Sesamum indicum L.) locally named as "Selit" is economically important. The sesame value chain presented in Figure 1, involves organic sesame agriculture, sesame post-harvest practices, distribution and marketing, and processing. The economic value of sesame was reported within the range of USD 307,512 - 619,033 million annually in the year of 2011-2017 with an average yield of 756.5 - $906.3 \mathrm{~kg} / \mathrm{ha}$ considering agro-climatic condition, season, rainfall, and other determinant parameters variability [7]. Sesame plantation and production include land preparation, accessibility of improved seed and fertilizer, 
cultivation, weed prevention and use of pesticides, labour, and technology. Farmers interviewed revealed rainfall variability, weed prevention, climatic factors such as unexpected rainfall and wind at the stage of maturity, inadequate labour, or absences of technology for harvesting are critical challenges. Capsule colour or aging of sesame leaves are the indicators for harvesting. The cuts of sesame bundle locally named as "Hilla" placed in the field are susceptible to insects such as termite, sesame webworm, sesame seed bug, gall midge, and others causes sesame post-harvest loss and quality defect. To reduce the loss and quality defect of sesame studies suggested the bundles placed in a plastic mat of clean area or application of pesticides around the bundle to prevent insect attack. After 15 days of drying with its parent plant seed is thresh separated in a plastic mat. However, During harvesting and early post-harvest practices about $17 \%$ of sesame was lost due to poor/inappropriate farming, delaying harvesting time, shattering, and field drying, threshing, loading, and unloading during bundle transportation excluding storage loss [51].

Sesame stored in cooperative warehouse build-up of stainless steel experiences high loss. The stainless steel warehouse increases inside environment hotness which is conducive for microbial growth. Furthermore, the external environment of the warehouse was not clear of grass, shrub, and trees to hide out macro-organisms such as mice and rats, birds, and termites to attack sesame during storage. The unions' warehouses were, however comparably clean, built of cinder concrete block smoothly cemented floor and wall. The arrangement of sesame packs in a sack of $100 \mathrm{~kg}$ in the cemented warehouses with adequate space and recommended opening for ventilation. Unprocessed sesame seed value addition includes cleaning, colour sorting, and de-hulling process satisfying the sanitary and phytosanitary requirement. Regulatory authorities regulate sesame agriculture and trains farmers to avoid the use of unregistered or unpermitted pesticides in the farm, harvesting, and storage. To overcome the challenges in the sesame value chain studies conducted in Myanmar suggested that integrated sesame agriculture and value chain is critical to improve sesame productivity and reduce sesame loss [54].

Sesame is one of the main export crops in foreign currency earnings to the country and income generation. EXC certifies sesame via examining the quality and grading based on impurity level, contrasting colour, and identifying the appropriate market channel, as presented in Table 3. Sesame marketing continues to grow conversely quality defects and inadequate value addition, illegal broker interference, lack of storage and transportation, inadequate infrastructure, the disparity between stakeholders, limited access to market, and low price are the major challenges. Besides export earnings from the unprocessed seed, sesame is locally used for food and non-food application. It is a primary ingredient for refined and unrefined edible oil extraction. Sesame cake is a by-product of edible oil extraction used for animal feed and soap production. Sesame straw is also used for animal feed and biomass energy sources in the cement industry. 
Table 3. Grading parameters of western Tigray sesame seed based on the Ethiopian commodity exchange.

\begin{tabular}{|c|c|c|c|c|c|}
\hline Parameters & Grade 1 & Grade 2 & Grade 3 & Grade 4 & UG \\
\hline \multicolumn{6}{|c|}{ Whitish Humera and reddish sesame seed } \\
\hline $\begin{array}{l}\text { Total Impurity (Foreign Matter } \\
\text { and DSW) Max \% by weight }\end{array}$ & 1 & 3 & 5 & 7 & 15 \\
\hline $\begin{array}{l}\text { Contrasting Colour, } \\
\max \% \text { by Weight }\end{array}$ & 1 & 2 & 4 & 6 & 7 \\
\hline \multicolumn{6}{|c|}{ Mixed Humera and Mixed Reddish Sesame Seed } \\
\hline $\begin{array}{l}\text { Total Impurity (Foreign Matter } \\
\text { and DSW) Max \% by weight }\end{array}$ & 1 & 3 & 5 & 7 & 15 \\
\hline $\begin{array}{l}\text { Contrasting Colour, } \\
\text { max \% by Weight }\end{array}$ & & & $>7$ & & \\
\hline
\end{tabular}

DSW: Damaged, Shriveled, Weevil bored.

\subsection{CSO Extraction Establishment Suitability and Hygienic Condition}

The suitability of the extraction plant for oil extraction was determined, preconditions and criteria to fulfil in the CSO extraction premises summarized in Table 4. Oil extraction plant located in a government-built lodging designed for small and medium manufacturing enterprise in proximity to the sesame farm, infrastructure, and market free from nearby chemical manufacturing plant or sewage accumulation/treatment. The plant was built with cinder concrete blocks, the wall and floor were smoothly cemented and a stainless-steel cover of the roof with appropriate drainage system and sanitation friendly. Though the exterior environment was clear of grass, shrub, and trees and yet dusty due to the dry and windy environment and randomly pole-installed light for security purposes. Studies suggested that lightening ensures quality preservation, sanitary purpose, security, and avoid insect attraction and contamination [55]. The opening was sealed to avoid insects and rodent entrances, however, the only door for raw material and end product dispatch was old and folded somehow. The extraction equipment (milling, pressing, and filtration machine) was suitable. Nevertheless, overall sanitation and handling practices were unfortunate. The challenges identified were limited access to sanitary inputs such as enough water, detergents, and other cleaning inputs, poor sanitation infrastructure/structure including operation and maintenance, and poor hygiene habits. Lack of written sanitation program and presentation in the appropriate location, sporadic cleaning of the machines and premises, inadequate supply of hygienic materials, and movement of workers liable for dirt accumulation and cross-contamination. Sesame seed was procured either from farmers, cooperatives and other retailers without quality specification contribute to affect quality and safety aspects. Sesame store in the extraction plant lacks ventilation and temperature control creates a conducive condition for the revival of contaminants due to the warm climate condition and unclean premises. 
Table 4. Assessment of the CSO extraction establishment suitability and hygienic condition.

\begin{tabular}{|c|c|c|c|}
\hline Premises Assessment & Yes & No & Status \\
\hline $\begin{array}{l}\text { Is the extraction establishment located proximity to raw } \\
\text { material, infrastructure and market? }\end{array}$ & $\sqrt{ }$ & & Suitable \\
\hline $\begin{array}{l}\text { Is the extraction establishment located in a weed, grass, } \\
\text { brush, and dust free environment, so that pest and } \\
\text { macro-organisms cannot hide? }\end{array}$ & & $\sqrt{ }$ & Unsuitable \\
\hline Is the internal premises smooth and hygiene friendly? & & $\sqrt{ }$ & Unsuitable \\
\hline $\begin{array}{l}\text { Does the establishment have a separated storage of raw } \\
\text { material and end product? }\end{array}$ & $\sqrt{ }$ & & Suitable \\
\hline $\begin{array}{l}\text { Is the storage and production area doors and windows } \\
\text { have fine mesh screens or tightly sealed to keep out insects? }\end{array}$ & $\sqrt{ }$ & & Suitable \\
\hline $\begin{array}{l}\text { Is there any leaks/cracks in the floor, roof, window to } \\
\text { allow sky light, and pest entry or water leak? }\end{array}$ & & $\sqrt{ }$ & Suitable \\
\hline $\begin{array}{l}\text { Is the establishment designed with a proper drainage and } \\
\text { waste disposal system? }\end{array}$ & $\sqrt{ }$ & & Suitable \\
\hline \multicolumn{4}{|l|}{ Suitability for CSO extraction } \\
\hline Is the establishment primarily designed for oil extraction? & & $\sqrt{ }$ & Suitable \\
\hline $\begin{array}{l}\text { Is the equipment primarily designed or suitable for oil } \\
\text { extraction? }\end{array}$ & $\sqrt{ }$ & & Suitable \\
\hline $\begin{array}{l}\text { Does the establishment have equipment calibration, } \\
\text { maintenance and monitoring plan with appropriate layout? }\end{array}$ & $\sqrt{ }$ & & Suitable \\
\hline $\begin{array}{l}\text { Is the oil extraction establishment have quality } \\
\text { Specification, control and monitory? }\end{array}$ & & $\sqrt{ }$ & Unsuitable \\
\hline $\begin{array}{l}\text { Is the establishment equipped with temperature, } \\
\text { ventilation, lightening, pest, and humidity control? }\end{array}$ & & $\sqrt{ }$ & Unsuitable \\
\hline Does the establishment have transportation? & $\sqrt{ }$ & & Suitable \\
\hline \multicolumn{4}{|l|}{ Sanitary condition } \\
\hline Is the water used in the establishment treated? & & $\sqrt{ }$ & Unsuitable \\
\hline $\begin{array}{l}\text { Is the cleaning and washing facilities furnished with soap, } \\
\text { detergents, and cleaning equipment for personal and } \\
\text { establishment sanitary with enough water supply? }\end{array}$ & $\sqrt{ }$ & & Suitable \\
\hline $\begin{array}{l}\text { Is there any presence of domestic animals around the } \\
\text { establishment? }\end{array}$ & $\sqrt{ }$ & & Unsuitable \\
\hline $\begin{array}{l}\text { Is there enough protective clothing such as gown, } \\
\text { air cover and glove to oil handlers and operators? }\end{array}$ & $\sqrt{ }$ & & Suitable \\
\hline $\begin{array}{l}\text { Are the workers provided a separated area for eating and } \\
\text { drinking? }\end{array}$ & & $\sqrt{ }$ & Unsuitable \\
\hline $\begin{array}{l}\text { Is the waste quickly removed to appropriate bins and } \\
\text { kept covered? }\end{array}$ & $\sqrt{ }$ & & Suitable \\
\hline Does the establishment have pest control system? & & $\sqrt{ }$ & Unsuitable \\
\hline
\end{tabular}




\subsection{Microbial Quality}

Microbial contaminants of aerobic bacteria, total Coliforms, fungi, Aspergillus species, and staphylococcus aureus were predominantly detected and quantified, presented in Table 5. Staphylococcus aureus and Aspergillus species were the potential pathogens identified. However, Escherichia coli, salmonella, and Shigella were not detected. The source of microbial contaminants was found to be the extraction establishment after examining the surface of equipment and premises, protective clothing, indoor, and outdoor air and water. Aerobic plate count bacteria (APC) are microbial hazards grow and survive in an aerobic and mesophilic environment. APC are important microbial indicators to assess product quality such as organoleptic quality and shelf life, manufacturing and hygienic practices, and cleanness of food establishment and product safety to a lesser extent [56] [57] and process efficiency for safer produce [58]. The APC for

Table 5. The Microbial count ( $\log _{10}$ colony forming unit) of supply, CSO, surface, protective cloth, indoor and outdoor environmental air during and after production in the crude sesame oil extraction facilities.

\begin{tabular}{|c|c|c|c|c|c|}
\hline Sample & $\begin{array}{l}\text { Aerobic } \\
\text { bacteria }\end{array}$ & $\begin{array}{l}\text { Total } \\
\text { coliforms }\end{array}$ & $\begin{array}{c}\text { Yeasts } \\
\text { and moulds }\end{array}$ & $\begin{array}{l}\text { Aspergillus } \\
\text { species }\end{array}$ & $\begin{array}{c}\text { Staphylococcus } \\
\text { aureus }\end{array}$ \\
\hline Sesame seed $\left(\log _{10} \mathrm{CFU} / \mathrm{g}\right)$ & - & - & $2.31^{\mathrm{cd}} \pm 0.13$ & $1.17^{\mathrm{b}} \pm 0.13$ & - \\
\hline Crude sesame oil $\left(\log _{10} \mathrm{CFU} / \mathrm{mg} / \mathrm{ml}\right)$ & $2.44^{\mathrm{cd}} \pm 0.07$ & $2.39^{\mathrm{d}} \pm 0.14$ & $2.31^{\mathrm{cd}} \pm 0.08$ & $1.33^{\mathrm{b}} \pm 0.01$ & $2.09^{\mathrm{dc}} \pm 0.12$ \\
\hline Municipal water $\left(\log _{10} \mathrm{CFU} / \mathrm{mg} / \mathrm{ml}\right)$ & $1.58^{\mathrm{f}} \pm 0.44$ & $1.46^{\mathrm{f}} \pm 0.28$ & - & - & $0.67^{\mathrm{g}} \pm 0.49$ \\
\hline Ground Water $\left(\log _{10} \mathrm{CFU} / \mathrm{mg} / \mathrm{ml}\right)$ & $2.76^{c} \pm 0.23$ & $3.41^{\mathrm{c}} \pm 0.14$ & - & - & $0.83^{\mathrm{gf}} \pm 0.31$ \\
\hline Animal manure $\left(\log _{10} \mathrm{CFU} / \mathrm{mg} / \mathrm{ml}\right)$ & - & $5.81^{\mathrm{a}} \pm 0.48$ & - & - & $1.24^{\mathrm{gef}} \pm 0.28$ \\
\hline \multicolumn{6}{|l|}{ Surface $\left(\left(\log \mathrm{CFU} / \mathrm{m}^{2}\right)\right.$} \\
\hline Milling and pressing machine & $4.55^{\mathrm{ab}} \pm 0.12$ & $4.54^{\mathrm{b}} \pm 0.12$ & & - & $2.87^{\mathrm{b}} \pm 0.19$ \\
\hline Filtration machine & $5.06^{\mathrm{a}} \pm 0.09$ & $4.52^{\mathrm{b}} \pm 0.13$ & & - & $2.56^{\mathrm{bc}} \pm 0.31$ \\
\hline Filling machine & $4.34^{\mathrm{b}} \pm 0.15$ & $3.99^{b c} \pm 0.05$ & $3.73^{\mathrm{b}} \pm 0.09$ & - & - \\
\hline Floor of sesame store & $4.83^{\mathrm{ab}} \pm 0.13$ & $4.47^{\mathrm{b}} \pm 0.20$ & $4.47^{\mathrm{a}} \pm 0.07$ & $3.50^{\mathrm{a}} \pm 0.09$ & $3.22^{\mathrm{ab}} \pm 0.05$ \\
\hline Wall of the extraction plant & $4.62^{\mathrm{ab}} \pm 0.18$ & $4.28^{\mathrm{b}} \pm 0.11$ & $4.27^{\mathrm{ab}} \pm 0.20$ & $3.37^{\mathrm{a}} \pm 0.16$ & - \\
\hline \multicolumn{6}{|l|}{ Protective clothing } \\
\hline Clove (log CFU/glove) & $2.11^{\mathrm{def}} \pm 0.20$ & $1.78^{\mathrm{def}} \pm 0.22$ & $1.18^{\mathrm{e}} \pm 0.29$ & - & $3.77^{\mathrm{a}} \pm 0.36$ \\
\hline Gown (log CFU/gown) & $2.05^{\mathrm{def}} \pm 0.10$ & $2.23^{\text {ed }} \pm 0.20$ & $3.01^{c} \pm 0.33$ & - & $3.26^{\mathrm{ab}} \pm 0.14$ \\
\hline \multicolumn{6}{|l|}{ Air $(\log$ CFU/hr) } \\
\hline Indoor air during production & $2.55^{\mathrm{cd}} \pm 0.19$ & $1.63^{\mathrm{ef}} \pm 0.28$ & $2.06^{\mathrm{d}} \pm 0.11$ & - & $1.82^{\mathrm{de}} \pm 0.04$ \\
\hline Indoor air after production & $2.17^{\mathrm{de}} \pm 0.18$ & $1.36^{\mathrm{f}} \pm 0.39$ & $1.73^{\mathrm{de}} \pm 0.23$ & - & $1.54^{\mathrm{def}} \pm 0.09$ \\
\hline Outdoor air during production & $1.18^{\mathrm{ef}} \pm 0.10$ & $1.70^{\text {ef }} \pm 0.16$ & $1.70^{\mathrm{de}} \pm 0.57$ & - & $1.35^{\mathrm{def}} \pm 0.18$ \\
\hline Outdoor air after production & $1.79^{\mathrm{ef}} \pm 0.08$ & $1.73^{\mathrm{def}} \pm 0.12$ & $1.79^{\mathrm{de}} \pm 0.08$ & - & $0.74^{\mathrm{g}} \pm 0.20$ \\
\hline
\end{tabular}

All values indicates $\log _{10}$ colony forming unit \pm standard deviation. Values with different superscript letters in each column are significantly different $(\mathrm{P}$-value $<0.05)$. 
CSO was $2.44 \log _{10} \mathrm{CFU} / \mathrm{ml}$ oil lower than the acceptance limit of $<6 \log _{10}$ $\mathrm{CFU} / \mathrm{ml}$ for foods without cooking [59]. The sources of APC contamination were the surface of equipment and premises $\left(4.68 \log _{10} \mathrm{CFU} / \mathrm{m}^{2}\right)$, water $(2.16$ $\left.\log _{10} \mathrm{CFU} / \mathrm{ml}\right)$, Indoor and outdoor air $\left(2.08 \log _{10} \mathrm{CFU} / \mathrm{hr}\right)$, and personal protective clothes (2.08 $\log _{10} \mathrm{CFU} /$ clothes) with significant variability. Groundwater was immensely contaminated than pipe water and indoor air during production significantly with higher counts. The prevalence of APC explains unhygienic handling, inefficient and sporadic cleaning as well as environmental factors such as warm climatic conditions, dry and dusty environments.

Coliforms are non-spore-forming and Enterobacteriaceae group of gram-negative road-shaped microbial flora capable of lactose fermentation and survive in soil, water, human and animal intestine during aerobic and facultative anaerobic conditions at nearly body temperature. Coliforms are indicator pathogenic microorganisms originating from the gastrointestinal tract with a potential to cause food and waterborne illness as a result of poor environmental sanitation of food establishment, food handlers, and improper food processing and handling conditions [60] [61]. Total Coliforms identified in CSO were as large as $2.39 \log _{10}$ $\mathrm{CFU} / \mathrm{ml}$ oil lower than the acceptance limit of $<4 \log _{10} \mathrm{CFU} / \mathrm{ml}$ applied to processed foods. However, coliforms detected in animal manure (5.81 $\log _{10}$ $\mathrm{CFU} / \mathrm{ml})$, the surface of equipment, and establishment premise (4.36 $\log _{10}$ $\mathrm{CFU} / \mathrm{m}^{2}$ ) were above the limit explains the inefficiency of hygienic practices in the premises and equipment. Coliforms in water $\left(2.43 \log _{10} \mathrm{CFU} / \mathrm{ml}\right)$, protective clothing $\left(2.0 \log _{10} \mathrm{CFU} / \mathrm{m}^{2}\right)$ and environmental air $\left(1.6 \log \mathrm{CFU} / \mathrm{m}^{3}\right)$ below the limit. The prevalence of coliforms in the product, protective clothing, surface, and environment confirms that poor hygienic practices compromise CSO safety and quality. Nevertheless, E. coli was not detected in CSO.

Yeasts/moulds a microbial flora has grown and survived in a wide range of environmental conditions such as humidity, water activity, temperature, time, acidity, and air [62] [63] and in wider agricultural produce, food, food processing and storage establishments [64]. Fungi are categorized as beneficial and hazardous microbial flora with diverse physical features [65]. However, hazardous yeasts/moulds to humans and animals are gaining attention due to their diverse pathogenic character and toxic metabolites [66] [67], resistances during handling, processing, and cooking [68]. Fungi were detected in sesame seed, sesame oil, and associated surfaces, environment and protective clothing. Surfaces of extraction equipment and premises were found convenient environments for yeasts/moulds growth and survival $\left(4.15 \log _{10} \mathrm{CFU} / \mathrm{m}^{2}\right)$ whereas the filling machine was detected a lower colony count. The average fungi identified in the indoor and outdoor environmental air during and after production was also as high as $1.7-2.06 \log _{10} \mathrm{CFU} / \mathrm{hr}$ with significant variability. Yeasts and moulds detected were variable in size, shape, texture, and colour explains diversified yeasts and moulds species were prevalent due to convenient environmental temperature $\left(22^{\circ} \mathrm{C}-27^{\circ} \mathrm{C}\right)$, humid environment, and poor hygienic practices. Yeasts and mould colonies with powdery and fluffy white, fluffy black, deep 
brown, green-black, mountain-like rough yellow colonies of different sizes and structures were detected. In the meantime, yeasts/moulds pathogenicity was confirmed as the Aspergillus species were detected in a Sabouraud Dextrose Agar with chloramphenicol powder added as a bacterial growth inhibitor at $25^{\circ} \mathrm{C}$ during 5 - 7 days of incubation. The prevalence of Aspergillus species was confirmed $\left(3.45 \log _{10} \mathrm{CFU} / \mathrm{m}^{2}\right)$ on the selected surface of the storage and extraction facilities and $1.25 \log _{10} \mathrm{CFU} / \mathrm{ml}$ in sesame seed and CSO with insignificant variability.

Staphylococcus aureus is a small $(0.5-1.5 \mu \mathrm{m})$ spherical gram-positive facultative anaerobic multi-resistant bacteria of Micrococcaceae family staphylococcus genera. Staphylococcus aureus is catalase-positive, and thermostable [69] and a potential animal and human pathogen associated with poor hygienic human, animal, and environmental conditions. Staphylococcal poisoning is known worldwide as it produces Staphylococcal enterotoxin when ingested the strain/its toxins in food or in contact with surfaces contaminated with Staphylococcus aureus. Staphylococcus aureus, a potential infectious pathogenic bacteria were detected in CSO as large numbers as $2.09 \log _{10} \mathrm{CFU} / \mathrm{ml}$ few hours after production which is below the acceptable limit $\left(<4 \log _{10} \mathrm{CFU} / \mathrm{ml}\right)$. However, Staphylococcus aureus growth might be continued during CSO storage. It was also detected at the surface of the equipment and different sites in the CSO establishment, protective clothing. This was due to unhygienic and inappropriate handling practices. Studies have reported Staphylococcus aureus to survive in a wide range of surfaces including plastics and fabrics [70], household and marketing equipment, glass, pipes, and metallic containers [71] [72], bottled and unblotted water of different sources [73], animal and animal by-products [74] and food [75], bio-aerosol [76], public areas and hospitals [9]. It survives in a wide range of conditions such as relative humidity, high gradient temperature, salinity, diverse environment, time and light exposure [70] [73] due to unhygienic practices and inappropriate food-handling [77].

\section{Conclusion}

Sesame value chain involves sesame agriculture, processors and consumers. However, value addition and local processing skills ineffectiveness experiencing post-harvest and quality loss. The sesame oil extraction establishment was suitable. However, the design of premises and hygienic practices were insufficient. And yet, quality degradation predominantly discoloration, off-flavour, and storage instability of sesame oil is a challenge. Both spoilage and pathogenic microorganisms were detected in CSO, sesame seed, water, and related surfaces in the establishment. Aerobic bacteria, total Coliforms, and yeasts and moulds were among the spoilage microbes, and Aspergillus species and staphylococcus aureus were potential pathogens detected in CSO, supplies, and establishment environment while E. coli, salmonella and Shigella were not detected. The causes for the prevalence of spoilage and pathogenic microorganisms were primarily poor 
hygienic practices and the inappropriate handling such as high moisture content of the seed and CSO. In the meantime, the use of raw CSO should be avoided unless cooked optimally. Further investigation is critical to minimize health burden, promote appropriate handling and hygienic practices, and use organic anti-microbial preservatives.

\section{Acknowledgements}

We acknowledge the Dutch organization for internationalization in education (Nuffic), Organization for women in science for the developing world (OWSD), and the World Academy of Sciences (TWAS) for financial support. Tigray Sesame oil extraction plant, Addis Adigrat pharmaceutical industry for allowing us to use their facilities and technical support.

\section{Funding}

This work was supported by the Nuffic, Organization for women in science for the developing world and the World Academy of Sciences.

\section{Conflicts of Interest}

The authors declare there is no conflict of interest.

\section{References}

[1] Amare, M., Fisseha, D. and Andreasen, C. (2019) The Effect of N and P Fertilizers on Yield and Yield Components of Sesame (Sesamum indicum L.) in Low-Fertile Soil of North-Western Ethiopia. Agriculture, 9, Article No. 227. https://doi.org/10.3390/agriculture9100227

[2] Mawcha, T.K., Gebresalassie, M.G., Gebreyohannes, M.H. and Kiros, A.M. (2021) Description of Climatic Factors for Informed Sesame (Sesamum indicum L.) Cultivation in Kafta Humera District, North Ethiopia. Sustainable Environment, 7, Article ID: 1903699. https://doi.org/10.1080/27658511.2021.1903699

[3] Barreto-Salazar, L.E., Rochín-Medina, J.J., Picos-Ponce, J.C., Castro-Palazuelos, D.E. and Rubio-Astorga, G.J. (2021) Control of Vapor Pressure Deficit (VPD) on Black Sesame Seed (Sesamum indicum L.) Sprout Production in a Micro-Greenhouse Using Intelligent Control. Applied Sciences, 11, Article No. 7957. https://doi.org/10.3390/app11177957

[4] Teklu, D.H., Shimelis, H., Tesfaye, A. and Abady, S. (2021) Appraisal of the Sesame Production Opportunities and Constraints, and Farmer-Preferred Varieties and Traits, in Eastern and Southwestern Ethiopia. Sustainability, 13, Article ID: 11202. https://doi.org/10.3390/su132011202

[5] Gebregergis, Z., Assefa, D. and Fitwy, I. (2018) Sesame Sowing Date and Insecticide Application Frequency to Control Sesame Webworm Antigastra catalaunalis (Duponchel) in Humera, Northern Ethiopia. Agriculture \& Food Security, 7, Article No. 39. https://doi.org/10.1186/s40066-018-0190-4

[6] Baraki, F., Gebregergis, Z., Belay, Y., Berhe, M., Teame, G., Hassen, M., et al. (2020) Multivariate Analysis for Yield and Yield-Related Traits of Sesame (Sesamum indicum L.) Genotypes. Heliyon, 6, e05295.

https://doi.org/10.1016/j.heliyon.2020.e05295 
[7] Baraki, F. and Berhe, M. (2019) Evaluating Performance of Sesame (Sesamum indicum L.) Genotypes in Different Growing Seasons in Northern Ethiopia. International Journal of Agronomy, 2019, Article ID: 7804621. https://doi.org/https://doi.org/10.1155/2019/7804621

[8] Almanza, B.A. and Ghiselli, R. (1998) Implementation and Cost of HACCP in a Grill Type Operation. Foodservice Research International, 10, 107-124. https://doi.org/10.1111/j.1745-4506.1998.tb00145.x

[9] ICMSF (2006) Use of Epidemiologic Data to Measure the Impact of Food Safety Control Programs. Food Control, 17, 825-837. https://doi.org/10.1016/j.foodcont.2005.05.010

[10] Arvanitoyannis, I.S. and Traikou, A. (2005) A Comprehensive Review of the Implementation of Hazard Analysis Critical Control Point (HACCP) to the Production of Flour and Flour-Based Products. Critical Reviews in Food Science and $\mathrm{Nu}$ trition, 45, 327-370. https://doi.org/10.1080/10408390590967694

[11] Arvanitoyannis, I.S. and Varzakas, T.H. (2009) Application of ISO 22000 and Comparison with HACCP on Industrial Processing of Common Octopus (Octopus vulgaris) -Part I. International Journal of Food Science and Technology, 44, 58-78. https://doi.org/10.1111/j.1365-2621.2007.01666.x

[12] Aarnisalo, K., Tallavaara, K., Wirtanen, G., Maijala, R. and Raaska, L. (2006) The Hygienic Working Practices of Maintenance Personnel and Equipment Hygiene in the Finnish Food Industry. Food Control, 17, 1001-1011. https://doi.org/10.1016/j.foodcont.2005.07.006

[13] Adzitey, F., Ekli, R. and Abu, A. (2019) Prevalence and Antibiotic Susceptibility of Staphylococcus aureus Isolated from Raw and Grilled Beef in Nyankpala Community in the Northern Region of Ghana. Cogent Food \& Agriculture, 5, Article ID: 1671115. https://doi.org/10.1080/23311932.2019.1671115.

[14] Sperber, W.H. (2005) HACCP and Transparency. Food Control, 16, 505-509. https://doi.org/10.1016/j.foodcont.2003.10.012

[15] Herath, D. and Henson, S. (2010) Barriers to HACCP Implementation: Evidence From the Food Processing Sector in Ontario, Canada. Agribusiness, 26, 265-279. https://doi.org/10.1002/agr.20245

[16] Uhlemann, A., Knox, J., Miller, M., Hafer, C., Vasquez, G., Ryan, M., et al. (2011) The Environment as an Unrecognized Reservoir for Community-Associated Methicillin Resistant Staphylococcus aureus USA300 : A Case-Control Study. PLoS ONE, 6, e22407. https://doi.org/10.1371/journal.pone.0022407

[17] Wu, S., Huang, J., Zhang, F., Wu, Q., Zhang, J., Dai, J., et al. (2019) Prevalence and Characterization of Staphylococcus aureus (MRSA) in China. Frontiers in Microbiology, 10, Article No. 304. https://doi.org/10.3389/fmicb.2019.00304

[18] Tsige, Y., Tadesse, S., G/Eyesus, T., Tefera, M. M., Amsalu, A., Menberu, M.A. and Gelaw, B. (2020) Prevalence of Methicillin-Resistant Staphylococcus aureus and Associated Risk Factors among Patients with Wound Infection at Referral Hospital, Northeast Ethiopia. Journal of Pathogens, 2020, Article ID: 3168325. https://doi.org/10.1155/2020/3168325

[19] Weldeselassie, M., Gugsa, G., Kumar, A., Tsegaye, Y., Awol, N., Ahmed, M., et al. (2020) Isolation and Characterization of Staphylococcus aureus From Food of Bovine Origin in Mekelle, Tigray, Ethiopia. The Open Microbiology Journal, 14, 234-241.

[20] Asiimwe, B.B., Baldan, R., Trovato, A. and Cirillo, D.M. (2017) Prevalence and Molecular Characteristics of Staphylococcus aureus, Including Methicillin Resistant Strains, Isolated from Bulk Can Milk and Raw Milk Products in Pastoral Communi- 
ties of South-West Uganda. BMC Infectious Diseases, 17, Article No. 422. https://doi.org/10.1186/s12879-017-2524-4

[21] Papadopoulos, P., Papadopoulos, L., Angelidis, A.S., Boukouvala, E., Zdragas, A., Papa, A., et al. (2018) Prevalence of Staphylococcus aureus and of Methicillin-Resistant $S$. aureus (MRSA) along the Production Chain of Dairy Products in North-Western Greece. Food Microbiology, 69, 43-50. https://doi.org/10.1016/j.fm.2017.07.016

[22] Hanson, B.M., Dressler, A.E., Harper, A.L., Scheibel, R.P., Wardyn, S.E., Roberts, L.K., et al. (2011) Prevalence of Staphylococcus aureus and Methicillin-Resistant Staphylococcus aureus (MRSA) on Retail Meat in Iowa. Journal of Infection and Public Health, 4, 169-174. https://doi.org/10.1016/j.jiph.2011.06.001

[23] Rortana, C., Nguyen-Viet, H., Tum, S., Unger, F., Boqvist, S., Dang-Xuan, S., et al. (2021) Prevalence of Salmonella spp. and Staphylococcus aureus in Chicken Meat and Pork from Cambodian Markets. Pathogens, 10, Article No. 556. https://doi.org/10.3390/pathogens10050556

[24] Sergelidis, D., Abrahim, A., Anagnostou, V., Govaris, A., Papadopoulos, T. and Papa, A. (2012) Prevalence, Distribution, and Antimicrobial Susceptibility of Staphylococcus aureus in Ready-to-Eat Salads and in the Environment of a Salad Manufacturing Plant in Northern Greece. Czech Journal of Food Sciences, 30, 285-291. https://doi.org/10.17221/37/2011-CJFS

[25] Yang, X., Zhang, J., Yu, S., Wu, Q., Guo, W. and Huang, J. (2016) Prevalence of Staphylococcus aureus and Methicillin-Resistant Staphylococcus aureus in Retail Ready-to-Eat Foods in China. Frontiers in Microbiology, 7, Article No. 816. https://doi.org/10.3389/fmicb.2016.00816

[26] Amissah, N.A., Buultjens, A.H., Ablordey, A., van Dam, L., Opoku-Ware, A., Baines, S.L., et al. (2017) Methicillin Resistant Staphylococcus aureus Transmission in a Ghanaian Burn Unit: The Importance of Active Surveillance in Resource-Limited Settings. Frontiers in Microbiology, 8, Article No. 1906. https://doi.org/10.3389/fmicb.2017.01906

[27] Ercoli, L., Gallina, S., Nia, Y., Primavilla, S., Guidi, F., Pierucci, B., et al. (2017) Investigation of a Staphylococcal Food Poisoning Outbreak from a Chantilly Cream Dessert, in Umbria (Italy). Foodborne Pathogens and Disease, 14, 407-413. https://doi.org/10.1089/fpd.2016.2267

[28] Johler, S., Tichaczek-dischinger, P.S., Sihto, H., Lehner, A., Adam, M. and Stephan, R. (2013) Outbreak of Staphylococcal Food Poisoning Due to SEA-Producing Staphylococcus aureus. Foodborne Pathogens and Disease, 10, 777-781. https://doi.org/10.1089/fpd.2013.1503

[29] Le Moing, V., Alla, F., Doco-Lecompte, T., Delahaye, F., Piroth, L., Chirouze, C., et al. (2015) Staphylococcus aureus Bloodstream Infection and Endocarditis-A Prospective Cohort Study. PLoS ONE, 10, e0127385.

https://doi.org/10.1371/journal.pone.0127385

[30] Nakatsuji, T., Chen, T.H., Two, A.M., Chun, K.A., Narala, S., Geha, R.S., et al. (2016) Staphylococcus aureus Exploits Epidermal Barrier Defects in Atopic Dermatitis to Trigger Cytokine Expression. Journal of Investigative Dermatology, 136, 2192-2200. https://doi.org/10.1016/j.jid.2016.05.127

[31] Javouhey, E., Bolze, P.A., Jamen, C., Lina, G., Badiou, C., Poyart, C., et al. (2018) Similarities and Differences between Staphylococcal and Streptococcal Toxic Shock Syndromes in Children: Results from a 30-Case Cohort. Frontiers in Pediatrics, 6, Article No. 360. https://doi.org/10.3389/fped.2018.00360

[32] Naber, C.K. (2009) Staphylococcus aureus Bacteremia: Epidemiology, Pathophysi- 
ology, and Management Strategies. Clinical Infectious Diseases, 48, S231-S237. https://doi.org/10.1086/598189

[33] Paulsen, J., Mehl, A., Askim, Å., Solligård, E., Åsvold, B.O. and Damås, J.K. (2015) Epidemiology and Outcome of Staphylococcus aureus Bloodstream Infection and Sepsis in a Norwegian County 1996-2011: An Observational Study. BMC Infectious Diseases, 15, Article No. 116. https://doi.org/10.1186/s12879-015-0849-4

[34] Claeys, K.C., Lagnf, A.M., Hallesy, J.A., Compton, M.T., Gravelin, A.L., Davis, S.L. and Rybaka, M.J. (2016) Pneumonia Caused by Methicillin-Resistant Staphylococcus aureus. Does Vancomycin Heteroresistance Matter? Antimicrobial Agents and Chemotherapy, 60, 1708-1716.

[35] Kavanagh, N., Ryan, E.J., Widaa, A., Sexton, G., Fennell, J., O’Rourke, S., et al. (2018) Staphylococcal Osteomyelitis: Disease Progression, Treatment Challenges, and Future Directions. Clinical Microbiology, 31, e00084-17.

[36] Bartlett, J.E., Kotrlik, J.W. and Higgins, C.C. (2001) Organizational Research : Determining Appropriate Sample Size in Survey Research. Information Technology, Learning and Performance Journal, 19, 43-50.

[37] Mikelonis, A.M., Abdel-Hady, A., Aslett, D., Ratliff, K., Touati, A., Archer, J., et al. (2020) Comparison of Surface Sampling Methods for an Extended Duration Outdoor Biological Contamination Study. Environmental Monitoring and Assessment, 192, Article No. 455. https://doi.org/10.1007/s10661-020-08434-8

[38] Napoli, C., Marcotrigiano, V. and Montagna, M.T. (2012) Air Sampling Procedures to Evaluate Microbial Contamination: A Comparison between Active and Passive Methods in Operating Theatres. BMC Public Health, 12, Article No. 594. https://doi.org/10.1186/1471-2458-12-594

[39] Hong, C.H., Todd, E.C.D. and Bahk, G.J. (2008) Aerobic Plate Counts as a Measure of Hazard Analysis Critical Control Point Effectiveness in a Pork Processing plant. Journal of Food Protection, 71, 1248-1252. https://doi.org/10.4315/0362-028X-71.6.1248

[40] Wohlsen, T., Bates, J., Vesey, G., Robinson, W.A. and Katouli, M. (2006) Evaluation of the Methods for Enumerating Coliform Bacteria from Water Samples Using Precise Reference Standards. Letters in Applied Microbiology, 42, 350-356. https://doi.org/10.1111/j.1472-765X.2006.01854.x

[41] Splichalova, A., Splichal, I., Sonnenborn, U. and Rada, V. (2014) A Modified MacConkey Agar for Selective Enumeration of Necrotoxigenic E. coli $\mathrm{O} 55$ and Probiotic E. coli Nissle 1917. Journal of Microbiological Methods, 104, 82-86. https://doi.org/10.1016/j.mimet.2014.06.017

[42] AOAC (2002) AOAC Official Method 997.02 Yeasts and Molds Counts in Foods. AOAC International.

[43] Visagie, C.M., Hirooka, Y., Tanney, J.B., Mwange, K., Meijer, M., Amend, A.S., et al. (2014) Aspergillus, Penicillium and Talaromyces Isolated from House Dust Samples Collected around the World. Studies in Mycology, 78, 63-139. https://doi.org/10.1016/j.simyco.2014.07.002

[44] Mengist, A., Mengistu, G. and Reta, A. (2018) Prevalence and Antimicrobial Susceptibility Pattern of Salmonella and Shigella among Food Handlers in Catering Establishments at Debre Markos University, Northwest Ethiopia. International Journal of Infectious Diseases, 75, 74-79. https://doi.org/10.1016/j.ijid.2018.08.008

[45] Reda, N., Ketema, B. and Tsige, K. (2017) Microbiological Quality and Safety of Some-Street-Vended Foods in Jimma Town, Southwestern Ethiopia. African Journal of Microbiology Research, 11, 574-585. https://doi.org/10.5897/AJMR2014.7326 
[46] Mezgebo, G.K., Mekonen, D.G. and Gebrezgiabher, K.T. (2021) Do Smallholder Farmers Ensure Resource Use Efficiency in Developing Countries? Technical Efficiency of Sesame Production in Western Tigrai, Ethiopia. Heliyon, 7, e07315. https://doi.org/10.1016/j.heliyon.2021.e07315

[47] Gebretsadik, D., Haji, J. and Tegegne, B. (2019) Sesame Post-Harvest Loss from Small-Scale Producers in Kafta Humera District, Ethiopia. Journal of Development and Agricultural Economics, 11, 33-42. https://doi.org/10.5897/jdae2017.0917

[48] Gebremedhn, M.B., Tessema, W., Gebre, G.G., Mawcha, K.T. and Assefa, M.K. (2019) Value Chain Analysis of Sesame (Sesamum indicum L.) in Humera District, Tigray, Ethiopia. Cogent Food \& Agriculture, 5, Article ID: 1705741. https://doi.org/10.1080/23311932.2019.1705741

[49] Gebre, Y.H. (2020) Evaluation of Farmers' Willingness to Pay (WTP) for Sesame Seed Driller Machine Rental Service in Kafta-Humera District, Western Tigray, Ethiopia. Asian Journal of Agricultural Extension, Economics \& Sociology, 38, 51-60.

[50] Golla, W.N., Kebede, A.A. and Kindeya, Y.B. (2020) Evaluation of Sesame Genotypes for Seed Yield and Bacterial Blight (Xanthomonas campestris pv. sesami) Disease Resistance in Optimum Moisture Areas of Western Tigray, Ethiopia. Cogent Food and Agriculture, 6, Article ID: 1771114. https://doi.org/10.1080/23311932.2020.1771114

[51] Neme, K., Tola, Y.B., Mohammed, A. and Tadesse, E. (2020) Postharvest Handling Practices and on Farm Estimation of Losses of Sesame (Sesamum indicum L.) Seeds: The Case of two Wollega Zones in Ethiopia. East African Journal of Sciences, 14, 23-38.

[52] Gebretsadik, D. (2020) Marketing Chain and Structure, Conduct and Performance of Sesame: The Case of Kafta Humera District, Western Zone of Tigray, Ethiopia. Asian Journal of Agricultural Extension, Economics \& Sociology, 38, 14-36.

[53] Goshme, D., Tegegne, B. and Zemedu, L. (2020) Determinants of Sesame Market Supply in Melokoza District, Southern Ethiopia. Food Science and Quality Management, 82, 9 p.

[54] Myint, D., Gilani, S.A., Kawase, M. and Watanabe, K.N. (2020) Sustainable Sesame (Sesamum indicum L.) Production through Improved Technology: An Overview of Production, Challenges, and Opportunities in Myanmar. Sustainability, 12, Article No. 3515. https://doi.org/10.3390/SU12093515

[55] D’Souza, C., Yuk, H.G., Khoo, G.H. and Zhou, W. (2015) Application of Light-Emitting Diodes in Food Production, Postharvest Preservation, and Microbiological Food Safety. Comprehensive Reviews in Food Science and Food Safety, 14, 719-740. https://doi.org/10.1111/1541-4337.12155

[56] Jaja, I.F., Green, E. and Muchenje, V. (2018) Aerobic Mesophilic, Coliform, Escherichia coli, and Staphylococcus aureus Counts of Raw Meat from the Formal and Informal Meat Sectors in South Africa. International Journal of Environmental Research and Public Health, 15, Article No. 819. https://doi.org/10.3390/ijerph15040819

[57] Maharjan, S., Rayamajhee, B., Chhetri, V.S., Sherchan, S.P., Panta, O.P. and Karki, T.B. (2019) Microbial Quality of Poultry Meat in an ISO 22000:2005 Certified Poultry Processing Plant of Kathmandu Valley. International Journal of Food Contamination, 6, Article No. 8. https://doi.org/10.1186/s40550-019-0078-5

[58] Ratajczak, M., Kubicka, M.M., Kamińska, D., Sawicka, P. and Długaszewska, J. (2015) Microbiological Quality of Non-Sterile Pharmaceutical Products. Saudi Pharmaceutical Journal, 23, 303-307. https://doi.org/10.1016/j.jsps.2014.11.015 
[59] Mailoa, M.N., Tapotubun, A.M. and Matrutty, T.E.A. (2017) Analysis Total Plate Counte (TPC) on Fresh Steak Tuna Applications Edible Coating Caulerpa sp during Stored at Chilling Temperature. Earth and Environmental Science, 89, Article ID: 012014. https://doi.org/10.1088/1755-1315/89/1/012014

[60] Blanch, A.R., Galofré, B., Lucena, F., Terradillos, A., Vilanova, X. and Ribas, F. (2007) Characterization of Bacterial Coliform Occurrences in Different Zones of a Drinking Water Distribution System. Journal of Applied Microbiology, 102, 711-721. https://doi.org/10.1111/j.1365-2672.2006.03141.x

[61] Nkere, C.K., Ibe, N.I. and Iroegbu, C.U. (2011) Bacteriological Quality of Foods and Water Sold by Vendors and in Restaurants in Nsukka, Enugu State, Nigeria: A Comparative Study of Three Microbiological Methods. Journal of Health, Population and Nutrition, 29, 560-566.

[62] Leggieri, M.C., Decontardi, S., Bertuzzi, T., Pietri, A. and Battilani, P. (2017) Modeling Growth and Toxin Production of Toxigenic Fungi Signaled in Cheese under Different Temperature and Water Activity Regimes. Toxins, 9, Article No. 4. https://doi.org/10.3390/toxins9010004

[63] Lahouar, A., Marin, S., Crespo-sempere, A., Saïd, S. and Sanchis, V. (2016) Effects of Temperature, Water Activity and Incubation Time on Fungal Growth and Aflatoxin B1 Production by Toxinogenic Aspergillus flavus Isolates on Sorghum Seeds. Revista Argentina de Microbiología, 48, 78-85.

https://doi.org/10.1016/j.ram.2015.10.001

[64] Visagie, C.M., Houbraken, J., Frisvad, J.C., Hong, S.B., Klaassen, C.H.W., Perrone, G., et al. (2014) Identification and Nomenclature of the Genus Penicillium. Studies in Mycology, 78, 343-371. https://doi.org/10.1016/j.simyco.2014.09.001

[65] Hutkins, R.W. (2006) Microorganismss and Metabolism. In: Hutkins, R.W., Ed., Microbiology and Technology of Feremented Foods, Blackwell Publishing, Hoboken, 15-66. https://doi.org/10.1002/9780470277515.ch2

[66] Amaike, S. and Keller, N.P. (2011) Aspergillus flavus. Annual Review of Phytopathology, 49, 107-133. https://doi.org/10.1146/annurev-phyto-072910-095221

[67] Frías-De-Leon, M.G., Paz, E.R., Atoche, C., Duarte-Escalante, E., Soschin, D.M. De, Acosta-Altamirano, G. and Reyes-Montes, M.R. (2018) Identification of Aspergillus tubingensis in a Primary Skin Infection. Journal de Mycologie Médicale, 28, 274-278. https://doi.org/10.1016/j.mycmed.2018.02.013

[68] Fountain, J.C., Khera, P., Yang, L., Nayak, S.N., Scully, B.T., Lee, R.D., et al. (2015) Resistance to Aspergillus flavus in Maize and Peanut: Molecular Biology, Breeding, Environmental Stress, and Future Perspectives. The Crop Journal, 3, 229-237. https://doi.org/10.1016/j.cj.2015.02.003

[69] Seo, K.S. and Bohach, G.A. (2013) Staphylococcus aureus. In: Doyle, M.P. and Buchanan, R.L., Eds., Food Microbiology: Fundamentals and Frontiers, American Society for Microbiology, Washington DC, 547-573. https://doi.org/10.1128/9781555818463

[70] Mcnitt, A.S., Petrunak, D.M. and Serensits, T.J. (2021) Survival of Staphylococcus aureus Applied to Poa pratensis L. and Synthetic Turf. International Turfgrass Society Research Journal, 1-13. https://doi.org/10.1002/its2.35

[71] Kusumaningrum, H.D., Riboldi, G., Hazeleger, W.C. and Beumer, R.R. (2003) Survival of Foodborne Pathogens on Stainless Steel Surfaces and Cross-Contamination to Foods. International Journal of Food Microbiology, 85, 227-236. https://doi.org/10.1016/S0168-160500540-8

[72] Coughenour, C., Stevens, V. and Stetzenbach, L.D. (2011) An Evaluation of Methi- 
cillin-Resistant Staphylococcus aureus Survival on Five Environmental Surfaces. Microbial Drug Resistance, 17, 457-461. https://doi.org/10.1089/mdr.2011.0007

[73] Levin-Edens, E., Bonilla, N., Meschke, J.S. and Roberts, M.C. (2011) Survival of Environmental and Clinical Strains of Methicillin-Resistant Staphylococcus aureus [MRSA] in Marine and Fresh Waters. Water Research, 45, 5681-5686. https://doi.org/10.1016/j.watres.2011.08.037

[74] Dabele, D.T., Borena, B.M., Admasu, P., Gebremedhin, Z.E. and Marami, L.M. (2021) Prevalence and Risk Factors of Mastitis and Isolation, Identification and Antibiogram of Staphylococcus Species from Mastitis Positive Zebu Cows in Toke Kutaye, Cheliya, and Dendi Districts, West Shewa Zone, Oromia, Ethiopia. Infection and Drug Resistance, 14, 987-998. http://doi.org/10.2147/IDR.S295257

[75] Tesfaye, K., Gizaw, Z. and Haile, A.F. (2021) Prevalence of Mastitis and Phenotypic Characterization of Methicillin-Resistant Staphylococcus aureus in Lactating Dairy Cows of Selected Dairy Farms in and Around Adama Town, Central Ethiopia. Environmental Health Insights, 15, 8 p. https://doi.org/10.1177/11786302211021297

[76] Moon, K.W., Huh, E.H. and Jeong, H.C. (2014) Seasonal Evaluation of Bioaerosols from Indoor Air of Residential Apartments within the Metropolitan Area in South Korea. Environmental Monitoring and Assessment, 186, 2111-2120. https://doi.org/10.1007/s10661-013-3521-8

[77] Ho, J., Boost, M.V and O'Donoghue, M.M. (2015) Tracking Sources of Staphylococcus aureus Hand Contamination in Food Handlers by Spa Typing. American Journal of Infection Control, 43, 759-761. https://doi.org/10.1016/j.ajic.2015.03.022 